\title{
A case study of the coconut crab Birgus latro on Zanzibar highlights global threats and conservation solutions
}

\author{
Tim Caro, Haji Hamad, Rashid Suleiman Rashid, Ulrike Kloiber \\ Victoria M. Morgan, Ossi Nokelainen, Barnabas Caro, Ilaria Pretelli \\ Neil Cumberlidge and Monique Borgerhoff Mulder
}

\begin{abstract}
The coconut crab Birgus latro, the largest terrestrial decapod, is under threat in most parts of its geographical range. Its life cycle involves two biomes (restricted terrestrial habitats near the coast, and salt water currents of the tropical Indian and Pacific Oceans). Its dependence on coastal habitat means it is highly vulnerable to the habitat destruction that typically accompanies human population expansion along coastlines. Additionally, it has a slow reproductive rate and can reach large adult body sizes that, together with its slow movement when on land, make it highly susceptible to overharvesting. We studied the distribution and population changes of coconut crabs at 15 island sites in coastal Tanzania on the western edge of the species' geographical range. Our aim was to provide the data required for reassessment of the extinction risk status of this species, which, despite indications of sharp declines in many places, is currently categorized on the IUCN Red List as Data Deficient. Pemba Island, Zanzibar, in Tanzania, is an important refuge for B. latro but subpopulations are fragmented and exploited by children and fishers. We discovered that larger subpopulations are found in the presence of crops and farther away from people, whereas the largest adult coconut crabs are found on more remote island reserves and where crabs are not exploited. Remoteness and protection still offer hope for this species but there are also opportunities for protection
\end{abstract}

TIM CARO (Corresponding author, (D) orcid.org/0000-0001-6804-8519) Department of Wildlife, Fish \& Conservation Biology, University of California, Davis, California 95616, USA. E-mail tmcaro@ucdavis.edu

Haji Hamad and Rashid Suleiman Rashid Department of Forestry and NonRenewable Natural Resources, Wete, Pemba, Zanzibar, Tanzania

UlRIKE KLOIBER Chumbe Island Coral Park, Stonetown, Zanzibar, Tanzania

VICTORIa M. Morgan Department of Evolution and Ecology, University of California, Davis, USA

Ossi Nokelainen Department of Biological and Environmental Science, University of Jyväskylä, Jyväskylä, Finland

Barnabas Caro Berlin, Germany

Ilaria Pretelli Department of Human Behavior, Ecology and Culture, Max Planck Institute for Evolutionary Anthropology, Leipzig, Germany

Neil Cumberlidge Department of Biology, Northern Michigan University, Marquette, USA

Monique Borgerhoff Mulder ( (D orcid.org/0000-0003-1117-5984) Department of Anthropology, University of California, Davis, USA

Received 13 April 2019. Revision requested 3 July 2019.

Accepted 12 July 2019. First published online 22 April 2020. through local communities capitalizing on tourist revenue, a conservation solution that could be applied more generally across the species' range.

Keywords Birgus latro, coconut crab, conservation recommendations, IUCN, Pemba, population size, Tanzania

\section{Introduction}

The current wave of species extinctions in the tropics 1 is being driven by habitat loss and human exploitation. Species that are particularly susceptible to habitat conversion include those that depend on more than one biome to complete their life cycle, rendering them vulnerable to a wide variety of habitat changes or losses. Examples include marine turtles that breed on land (such as the leatherback turtle Dermochelys coriacea) and terrestrial anurans that reproduce in freshwater (such as the sky blue poison dart frog Hyloxalus azureiventris). Most land crabs (e.g. Gecarcinidae, Ocypodidae, Varunidae, Grapsidae and Mictyridae) and the terrestrial hermit crabs (Coenobitidae) also occupy two niches because juveniles and adults are entirely terrestrial but their larvae must develop at sea. This dependence on different habitats at different times in their life cycle makes it more difficult to assess the best way to conserve such species. Furthermore, long-lived species with long generation times are particularly susceptible to exploitation because recovery from population crashes can take years.

The coconut crab Birgus latro (family Coenobitidae) is the largest of the land crabs (Laidre, 2018). Adult coconut crabs are omnivorous and exclusively terrestrial, being so well adapted to life on land that they drown in water. Birgus latro occupies a vast oceanic range across the Indian and Western Pacific Oceans (Reyne, 1939) where it is found on islands and archipelagos, but today it is virtually absent from continental landmasses with suitable habitat, probably as a result of overharvesting by people and habitat destruction, and possibly from competition with other crabs (IUCN, 2016).

The life cycle of coconut crabs involves overland mating migrations to coastal areas where females carrying fertilized egg masses remain for 3-4 weeks before depositing their eggs into the sea (Amesbury, 1980; Brown \& Fielder, 1991). Coconut crab larvae spend several weeks in the plankton, 
carried by ocean currents, where they develop through several larval stages before emerging on to land in coastal areas as juveniles (glaucothoe) that, like most hermit crabs, protect their vulnerable abdomen inside an empty mollusc shell. At this stage, they are susceptible to predation by rats, pigs and ants. While coconut crabs grow, their abdomen becomes hardened and they no longer need the protection of a mollusc shell and can eventually attain $4 \mathrm{~kg}$ in weight as adults (Fletcher et al., 1990). Coconut crabs take 4-8 years to reach sexual maturity (Fletcher, 1993) and breeding females are encountered infrequently: only one berried female (carrying eggs) was identified out of 158 female crabs observed during the 3 years of this study. Most populations of coconut crabs have a sex ratio skewed towards males, but the reasons for this are unknown (Drew et al., 2012). Coconut crabs are restricted to coastal areas for reproductive reasons, and to humid forested habitat that contains rock crevices or cool burrows where they can hide during the heat of the day. Unfortunately, agricultural expansion is encroaching on this coastal scrub habitat, so that it is diminishing in many parts of the species' range.

The coconut crab was initially categorized as Rare on the IUCN Red List and changed to Data Deficient in 1996 (Drew et al., 2010), but there is a growing and widespread consensus from numerous studies across the species' range that many isolated populations are under sustained threat from human exploitation (Fletcher, 1993). The status of the coconut crab is currently being reassessed in the light of the threats to its coastal habitats from expansion of farmland, and overharvesting for both local consumption and export (Eldredge, 1996). The massive size and strength of coconut crabs (Oka et al., 2016) make this charismatic invertebrate an unusual candidate as a flagship species for raising conservation awareness on tropical islands. These crabs could also become an umbrella species for reducing the rapid decline of tropical island coastal forests and scrubland, a biome that is often overlooked by those trying to protect nearby mangrove forests. Threats to the coconut crab are similar in many parts of its vast global range, which includes two major tropical oceans (Eldredge, 1996), but the intensity of the threats mean there is insufficient time to gather data from every population.

Here we present a case study of the coconut crab in the Zanzibar Archipelago, to determine the status of these subpopulations and the threats to their existence, and to understand and resolve the threats that afflict this species worldwide. The Zanzibar Archipelago (i.e. Pemba and Unguja) lies off the coast of East Africa in the Western Indian Ocean along the Somalia-Kenya-Tanzania-Mozambique coastline (Fig. 1) at the western edge of the coconut crab's range. In Tanzania, where the species has no formal protection, there are populations of coconut crabs on the Pemba Island archipelago and on isolated islands off the coast of Unguja (sometimes erroneously called Zanzibar) and Dar es Salaam (Caro \& Morgan, 2018). The aims of this study

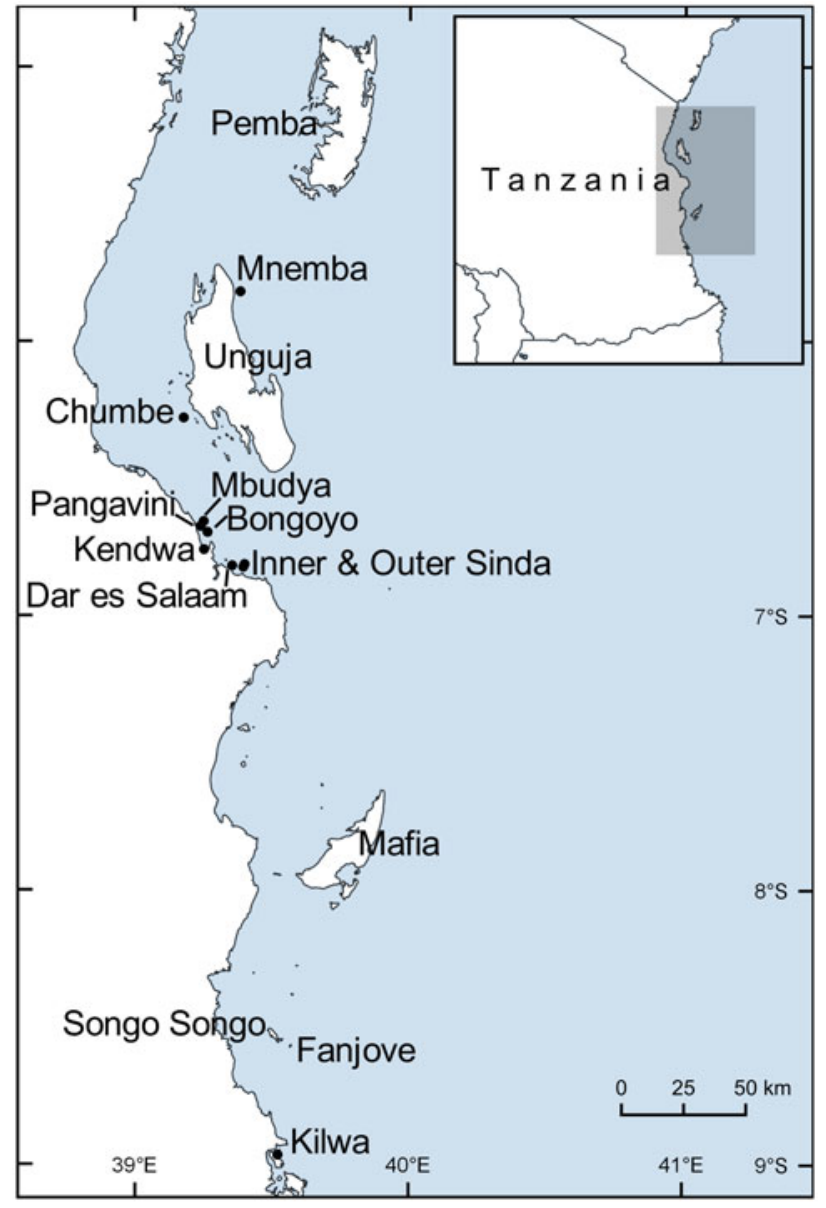

Fig. 1 Location of islands mentioned in the text and of Dar es Salaam and Kilwa, Tanzania.

were to monitor exploited populations of coconut crabs on Pemba and its outlying islands, and to monitor protected crab populations on Chumbe Island off Unguja, and on Mbudya and Bongoyo Islands close to Dar es Salaam.

We employed two different methods. The first was to make a comprehensive island-wide survey of the local children in every shehia (ward) around the entire coastline of Pemba, to establish the current distribution of coconut crabs on the island. The second was to measure coconut crabs at 12 sites on Pemba and the other three islands to determine crab population sizes, ongoing changes, habitat status, and the principal threats to these populations.

\section{Methods}

The distribution and population size of, and threats to, coconut crabs on Pemba were assessed using focus groups of local primary school children (typically 9-12 years old) because they are the principal collectors of these crabs. The children may have come from several different villages, but were chosen for their interest in forests and coastal areas and because they had experience foraging for wild animals. 
Focus groups were conducted by two people, who visited one village in every non-urban coastal shehia along the coastline of Pemba during July-December 2017. Groups of primary school children were asked (in Swahili) whether coconut crabs were present within the limits of their village, and if so, whether the crabs were very common, common, intermediate, uncommon or very uncommon (common categories were later collapsed into one category: 'many'; and uncommon categories into: 'few'), and whether they caught and ate these crabs.

We assessed the status of subpopulations of coconut crabs on Pemba and the surrounding islands at 12 sites that were selected for intensive fieldwork and visited for a total of 61 nights during July-August 2016, July-August 2017 and JulySeptember 2018. One of these sites was Misali Island, a marine reserve with no permanent residents but that is used by fishers who stay in temporary shelters/fishing camps (Abdullah et al., 1997). We also surveyed coconut crabs on Chumbe Island Coral Park (for 15 nights in September 2017, and July and September 2018), and on Bongoyo and Mbudya Island Marine Reserves (for 2 nights each in August 2018). Surveys started at 19.15, when crabs became active, and continued until 21.30-24.00. Sites were selected for study based on four criteria: (1) whether they were in a marine reserve system or not, (2) whether people (usually children) caught coconut crabs, (3) whether crabs were able to visit cropland (sweet potato, cassava and bean fields) adjacent to strips of coastal forest, and (4) whether the site was remote (not easily accessible by foot). In some analyses the coconut crab populations were compared to a completely protected crab population on Christmas Island, Australian territory, in the eastern Indian Ocean, which was surveyed in 2017 by VMM.

Coconut crabs were captured opportunistically, by hand, and all size classes were collected and then weighed in a plastic bucket and measured (see Fletcher, 1969; Nokelainen et al., 2018). The sex of individual crabs was determined by examination of the abdominal appendages: females have four large, highly setose biramous pairs of pleopods, whereas males have one slim uniramous pair of gonopods. Before release at the capture location, we painted a number on the back of each crab to prevent resampling.

Data were log transformed and averages (encounters) at each site per year ( $\mathrm{n}=28$ site-years) were analysed with SPSS 24 (IBM, Armonk, USA) using a mixed model with site as a repeated measure.

\section{Results}

\section{Distribution on Pemba}

Coconut crabs had a fragmented distribution on Pemba and its surrounding islands (Fig. 2a). Populations were abundant ('many') in only five of the 71 coastal shehias surveyed: in the far north-west (Tondoni and Makangale shehias), on Fundo Island to the west, and in Shamiani shehia and on the Kisiwa

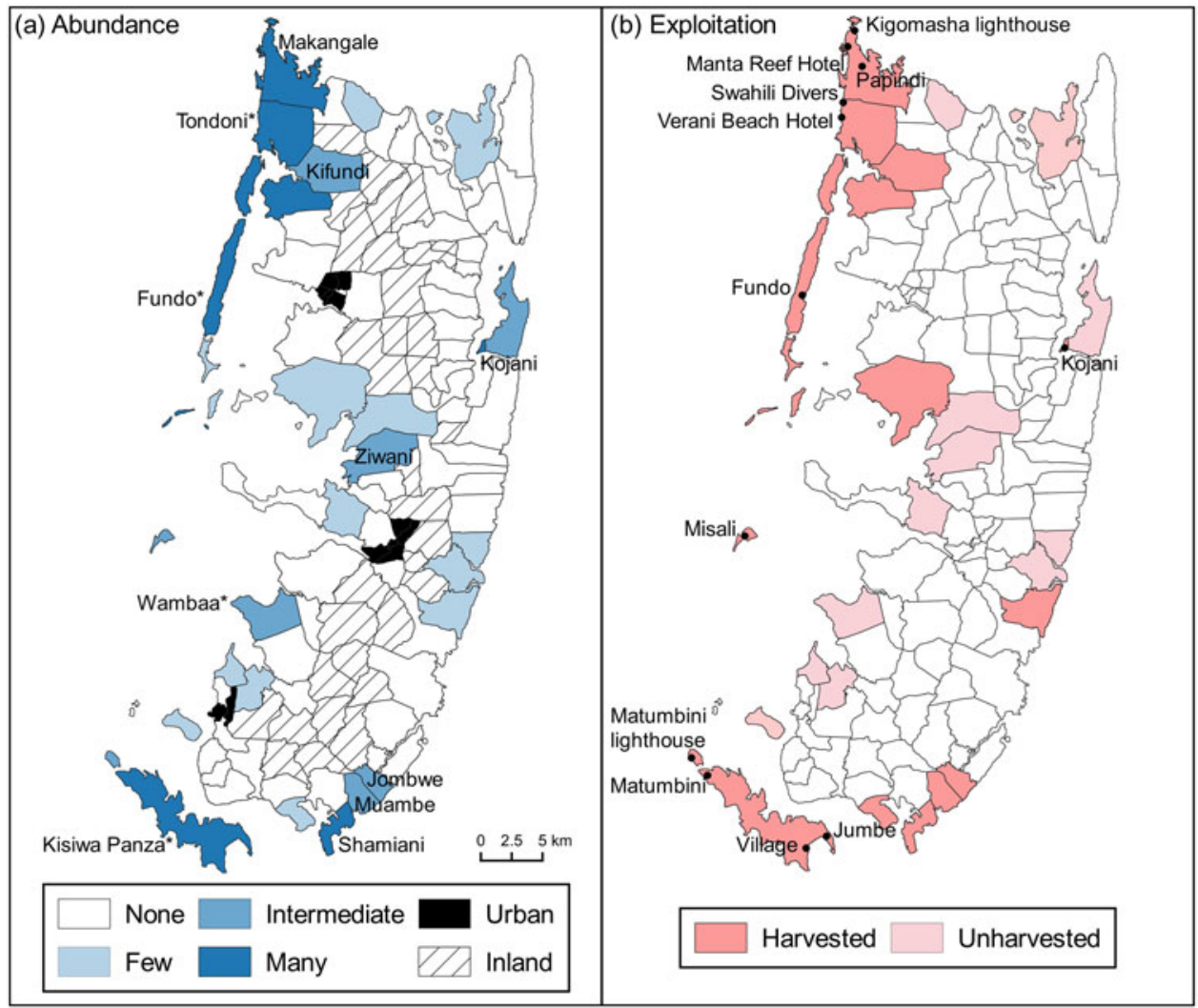

FIg. 2 Coconut crab Birgus latro abundance (a) and exploitation (b) in Pemba, Tanzania (by shehia), as reported through focus groups with local children in coastal areas; we did not visit urban shehias. In (a) shehias discussed in the text are named; starred names indicate shehias with sites suggested as sanctuaries. In (b) the locations of sites that we studied in depth are indicated. 


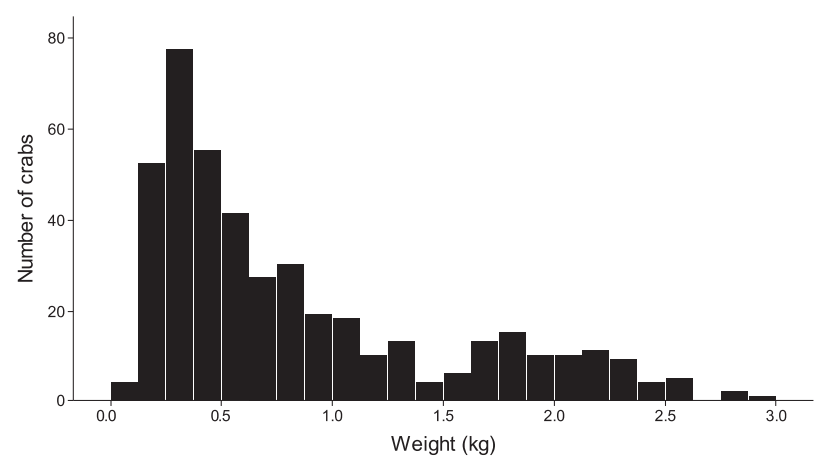

FIG. 3 Weight distribution of the 436 coconut crabs captured in Tanzania.

Panza Islands to the south. Populations were present in moderate numbers ('intermediate') in only six of the 71 coastal shehias surveyed (18.3\%) (Kojani Island, and Kifundi, Ziwani, Wambaa, Jombwe and Muambe; Fig. 2a). Children reported harvesting coconut crabs in most of the shehias where the crabs were present (Fig. 2b), with the exception of Kojani and Wambaa shehias where people do not eat these crabs even though crabs are reportedly found in 'intermediate' numbers (Fig. 2a).

\section{Life history data}

Captured coconut crabs had an apparent bimodal weight distribution across Tanzanian sites, with one peak at $<0.5 \mathrm{~kg}$ and a second, broader peak at c. $2.0 \mathrm{~kg}$ (Fig. 3). We used carapace lengths to calculate the years of poor crab recruitment using the relationship between carapace length and age from populations in Vanuatu in the Pacific (Fletcher et al., 1990). Assuming the same growth curve as on Vanuatu, coconut crabs on Pemba must have suffered a recruitment failure 18-20 years ago; a rat poisoning campaign on Chumbe Island (where many of our crabs were measured) in 1998 may have been responsible.

On Pemba, capture rates per night varied across sites (Table 1) with the highest being in some areas of Kisiwa Panza. These rates were higher than in marine reserves where these crabs are legally protected (Table 1). Elsewhere, on the Fundo Island, Kigomasha and Manta Reef sites, capture rates were also high (but we spent only one night at the last site).

These estimates of catch per unit effort are crude, however, because they do not account for time spent searching per night or the number of searchers. Taking these variables into account (Table 1), the areas with most crabs on Pemba were two of the islands in the Kisiwa Panza complex: Jumbe and Matumbini. Nonetheless, other areas on Kisiwa Panza near villages and at the lighthouse to the far west of the island chain hosted far fewer crabs. Sites in the north of Pemba such as Swahili Divers, Fundo Island, Kigomasha and Papindi all had relatively high crab densities by this measure, whereas the densities on Manta Reef and Verani Beach were lower. Table 1 shows that crab densities in marine reserves (other than Chumbe Island) were generally greater than those on Pemba itself, although parts of Kisiwa Panza, Swahili Divers, and Fundo were comparable.

We found relatively large crabs on Chumbe, Bongoyo and Kojani Islands although sample size was low on

TABLE 1 Measures of coconut crab Birgus latro abundance at 11 unprotected sites and four protected (reserve) sites in Tanzania, with mean weight, percentage of males, whether the crabs are eaten (and by whom) and close to agricultural crops, and whether the site is remote.

\begin{tabular}{|c|c|c|c|c|c|c|c|c|}
\hline & $\begin{array}{l}\text { No. of crabs } \\
\text { observed }\end{array}$ & $\begin{array}{l}\text { No. of } \\
\text { crabs/night }\end{array}$ & $\begin{array}{l}\text { No. of crabs/ } \\
\text { person/search } \\
\text { hour }\end{array}$ & $\begin{array}{l}\text { Weight } \\
(\mathrm{kg})\end{array}$ & $\begin{array}{l}\% \\
\text { male }\end{array}$ & Eaten? & $\begin{array}{l}\text { Close } \\
\text { to crops? }\end{array}$ & Remote $^{1}$ \\
\hline \multicolumn{9}{|l|}{ Unprotected } \\
\hline Matumbini (Kisiwa Panza) & 27 & 13.5 & 6.40 & 0.29 & 77.8 & By adults & Yes & Yes \\
\hline Jumbe (Kisiwa Panza) & 23 & 12.5 & 9.24 & 0.50 & 52.2 & By adults & Yes & Yes \\
\hline Fundo & 38 & 6.5 & 2.16 & 0.62 & 73.7 & By children & Yes & No \\
\hline Kigomasha & 54 & 5.1 & 1.97 & 0.48 & 44.4 & By children & Yes & No \\
\hline Manta Reef & 5 & 5.0 & 0.99 & 0.33 & 60.0 & By children & Yes & No \\
\hline Swahili Divers & 61 & 3.6 & 3.36 & 0.51 & 63.9 & By children & Yes & No \\
\hline Kojani & 3 & 3.0 & 0.40 & 1.09 & 33.3 & No & No & No \\
\hline Verani Beach & 21 & 2.6 & 0.82 & 0.75 & 66.7 & By children & Yes & No \\
\hline Papindi & 7 & 1.8 & 1.81 & 0.48 & 42.9 & No & No & No \\
\hline $\begin{array}{l}\text { Matumbini lighthouse } \\
\text { (Kisiwa Panza) }\end{array}$ & 1 & 1.0 & 0.20 & 0.25 & 0.0 & By fishers & No & Yes \\
\hline $\begin{array}{l}\text { Kisiwa Panza, near village } \\
\text { Reserves }\end{array}$ & 1 & 1.0 & 0.10 & 0.43 & 0.0 & By residents & Yes & No \\
\hline Chumbe & 144 & 9.6 & 21.99 & 1.29 & 72.2 & No & No & Yes \\
\hline Mbudya & 18 & 9.0 & 2.73 & 0.80 & 72.2 & No & No & Yes \\
\hline Bongoyo & 15 & 7.5 & 2.64 & 1.44 & 93.3 & No & No & Yes \\
\hline Misali & 28 & 4.0 & 2.88 & 0.71 & 89.3 & By fishers & No & Yes \\
\hline
\end{tabular}

${ }^{1}$ Not easily accessible by foot. 
TABLE 2 Per cent of coconut crabs in four weight quartiles at 10 sites on the Zanzibar archipelago and mainland Tanzania at which more than 10 individuals were measured, shown in rank order of large size (per cent in fourth quartile) and, for comparison, in the unexploited population of coconut crabs on Christmas Island, Australian Territory (surveyed in 2017 by VMM).

\begin{tabular}{lccccc}
\hline & \% in 1st quartile & \% in 2nd quartile & \% in 3rd quartile & \% in 4th quartile & Total no. of crabs \\
\hline Bongoyo & 20.0 & 6.7 & 26.7 & 46.7 & 15 \\
Chumbe & 5.6 & 21.5 & 42.4 & 30.6 & 144 \\
Fundo & 38.5 & 28.2 & 15.4 & 17.9 & 39 \\
Mbudya & 11.1 & 35.6 & 22.2 & 11.1 & 18 \\
Misali & 21.4 & 25.0 & 28.6 & 10.7 & 28 \\
Verani Beach & 35.0 & 21.7 & 30.0 & 10.0 & 20 \\
Jumbe (Kisiwa Panza) & 60.9 & 39.1 & 13.0 & 4.3 & 23 \\
Kigomasha & 45.7 & 33.9 & 22.0 & 4.3 & 4.7 \\
Swahili Divers & 42.4 & 22.2 & 0.0 & 0.0 & 59 \\
Matumbini (Kisiwa Panza) & 77.8 & 11.1 & 26.3 & 61.6 & 27 \\
Christmas Island & 1.0 & & & 99
\end{tabular}

Kojani $(\mathrm{N}=3)$; elsewhere crab mean weight was far below $1 \mathrm{~kg}$ (Table 1). Bigger crabs (i.e. with greater than median weight; Table 2) comprised more than half the crabs on Bongoyo and Chumbe, perhaps because individuals there take food from the kitchens at these protected tourist sites. Nonetheless, the weight of coconut crabs at Tanzanian sites was on average less than that of the crabs on the completely unexploited Christmas Island site. In contrast, crab populations at all other Pemban sites were principally composed of small individuals (Table 2). Sex ratios were always male-skewed except at two sites (Table 1).

Mean numbers of crabs observed per night each year were significantly positively associated with the presence of crops nearby (Table 3), and mean numbers of crabs encountered per person-hour spent searching were significantly positively associated with the presence of crops and the remoteness of the site. Crab weights were, however, significantly greater in marine reserves than in unprotected areas, and in the areas where crabs were not subject to human exploitation.

\section{Changes over time}

We sampled several sites over the course of 2 or 3 years. Crabs caught per night showed a decline over time at Verani Beach, at Papindi, and on both Misali and Chumbe Islands (both of which are marine reserves). Numbers of coconut crabs remained relatively constant at Swahili Divers, Kigomasha and Fundo Island, but increased at Jumbe and Matumbini on Kisiwa Panza (although the search effort was low at Matumbini; Fig. 4a). Median crab weights steadily increased at Swahili Divers, but steadily declined on Misali (Fig. 4b). These preliminary results, with crabs sampled for only 3 years, nevertheless indicate the presence of relatively robust populations at the Swahili Divers, Kigomasha, and Kisiwa Panza, Jumbe and Matumbini sites, but a decline in the number and size of crabs on Misali Island despite legal protection.
TABLE 3 Summary of mixed effects models (Type III effects) for annual measures of coconut crabs at 15 sites against whether the sites were protected, whether crabs were eaten at those sites, whether crops were present, and the remoteness of the sites (see Methods). Annual measures were included as a repeated measure at sites and only fixed effects were tested. The numerator degrees of freedom was 1 in all cases.

\begin{tabular}{|c|c|c|c|}
\hline Source & Denominator $\mathrm{df}$ & $F$ & $\mathrm{P}$ \\
\hline \multicolumn{4}{|c|}{$\log _{10}($ crabs per day +1$)$} \\
\hline Intercept & 7.675 & 132.959 & 0.000 \\
\hline Protected & 7.426 & 0.559 & 0.478 \\
\hline Eaten & 7.259 & 1.528 & 0.255 \\
\hline Crops & 9.091 & 5.281 & 0.047 \\
\hline Remoteness & 6.924 & 3.512 & 0.104 \\
\hline \multicolumn{4}{|c|}{$\log _{10}($ crabs per person search time +1$)$} \\
\hline Intercept & 10.324 & 66.720 & 0.000 \\
\hline Protected & 10.424 & 0.522 & 0.486 \\
\hline Eaten & 9.740 & 4.230 & 0.068 \\
\hline Crops & 13.898 & 6.799 & 0.021 \\
\hline Remoteness & 7.933 & 5.666 & 0.045 \\
\hline \multicolumn{4}{|c|}{$\log _{10}($ weight +1$)$} \\
\hline Intercept & 10.303 & 204.918 & 0.000 \\
\hline Protected & 10.039 & 8.795 & 0.014 \\
\hline Eaten & 9.910 & 5.446 & 0.042 \\
\hline Crops & 11.469 & 2.480 & 0.142 \\
\hline Remoteness & 9.720 & 1.779 & 0.213 \\
\hline
\end{tabular}

\section{Discussion}

\section{Distribution in Tanzania}

Informal discussions with researchers and wildlife officials suggest that coconut crabs have a highly fragmented distribution along Tanzania's coastline. Apparently there are virtually no populations remaining on mainland Tanzania although it is possible that small numbers survive north of Dar es Salaam. In contrast, the Dar es Salaam Marine Reserve system consists of nine small uninhabited islands, six of which (Mbudya, Bongoyo, Pangavini, Kendwa and Inner and 


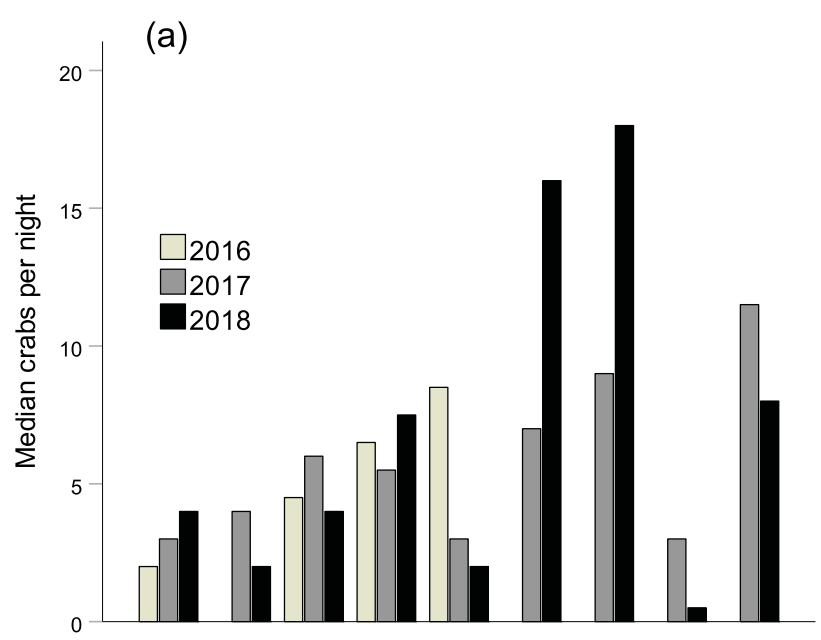

(b)

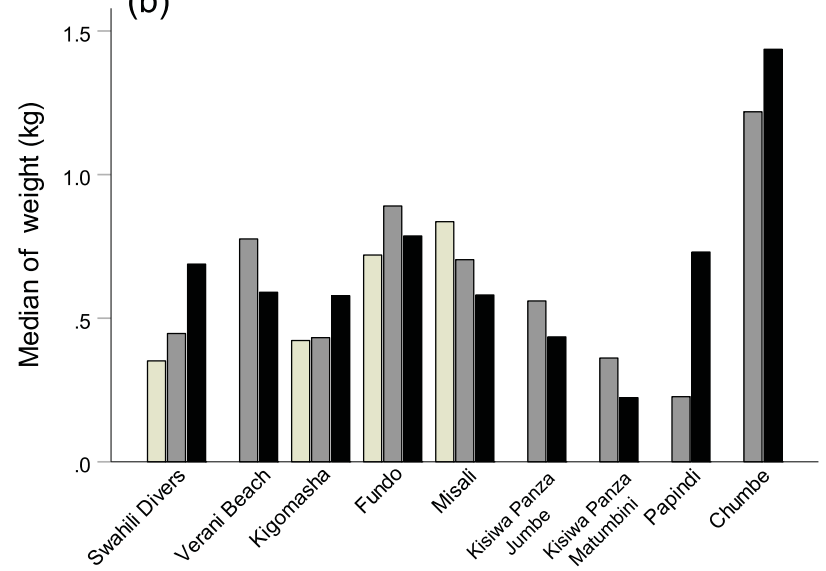

Fig. 4 (a) Median number of coconut crabs observed per night, and (b) median crab weight in 2016, 2017 and 2018 at the nine sites in Tanzania (Fig. 1) where we surveyed annually.

Outer Sinda Islands) are known to have coconut crab populations (Fig. 1). We surveyed coconut crabs at two of these islands and found an abundance around kitchens where food is prepared for day trip visitors. Crabs on Bongoyo were relatively large (mean $1.44 \mathrm{~kg}, \mathrm{~N}=15$ ), almost as large as the unexploited population on Christmas Island (mean $1.87 \mathrm{~kg}$, $\mathrm{N}=99$ ), suggesting a population that includes either old crabs, or younger crabs that were able to grow faster than normal by capitalizing on a constant supply of food scraps.

Further south, there are reports of a few coconut crabs on Mafia Island (C. Kiffner, pers. comm.) but some are found on offshore islands in the Mafia Archipelago. Only a few are present on Songo Songo and Fanjove Islands off the coast near Kilwa (E.M. Ryen, pers. comm.).

Further east, on Unguja, there are reportedly few coconut crabs, perhaps because of a lack of suitable crab habitat (a preponderance of sandy beaches) or as a result of past exploitation. Coconut crabs are found on the outlying Chumbe and Mnemba Islands, both of which are uninhabited and protected (Kilströmer \& Bergwall, 2013). Of all our sites, the highest number of coconut crabs was on Chumbe Island (Table 1) and many of these crabs were relatively large individuals (mean $1.29 \mathrm{~kg}, \mathrm{~N}=144$ ), comparable to those on Christmas Island.

\section{Status on Pemba Island}

The interview responses of children in coastal shehias indicated that the distribution of coconut crabs on Pemba is disjunct, with either only a few, or a complete absence of crabs in many of the shehias (Fig. 2a). We are certain that relatively large populations of coconut crabs remain in the north and south of Pemba, and principally on the offshore islands. It is possible that there are other populations on the northern and eastern coastlines of Pemba as yet undiscovered by us. Crab numbers on Kisiwa Panza Island and on Fundo are surprisingly large given the high human population densities there, and we now know there are other populations on small islands south of Fundo.

Coconut crabs are harvested throughout most of Pemba (Fig. 2b), principally by children who catch the crabs at night in the coral rag forest and in fields, and cook or play with them. Children similarly foraging for natural resources has been documented in many societies spanning five continents (see Lew-Levy et al., 2017, for a review). In addition, fishers may supplement their diet with coconut crabs when they camp overnight on these islands, and on Kisiwa Panza adults other than fishers consume coconut crabs. The status of the crab population in Misali Marine Reserve to the west of Pemba is of concern because the species was abundant there in 2016 but has since declined, with numbers close to the rangers' camp and one of the fishers' camps crashing in 2017-2018 (Fig. 4a). We suspect this is the result of fishers from Kisiwa Panza (who consume coconut crabs) using the Misali Marine Reserve as a temporary camp from which to base their fishing operations, bringing with them the culture of crab consumption. Earlier studies of coconut crab populations on Misali Island using mark-recapture methods found a similar pattern of rapidly decreasing populations, from 390 crabs in 2006 (Bowers, 2006), to 239 in 2014 (Merritt, 2014) and 157 in 2016 (Klein \& St. Denis, 2016). The latter authors suggested that poaching, lack of funding for the reserve, and mismanagement are responsible for the declining coconut crab population on Misali Island.

Kojani Island to the east of Pemba, and Ziwani and Wambaa shehias in the west of Pemba have intermediate numbers of coconut crabs, and there is no harvesting in these areas (Fig. 2). Differences in exploitation practices on Pemba vary from no offtake because people view crabs as disgusting (terming them wadudu, Swahili for insects), to hunting for fun by children, to harvesting for the table by both adults and children. These differences are intriguing and require further study from a cultural evolutionary perspective. 
Promising areas for conservation reform are in the north-west of Pemba (where there is a need for more education of children), and on Kisiwa Panza (where an education programme aimed at halting or reducing coconut crab exploitation is starting). The latter will be especially challenging because extensive harvesting of coconut crabs occurs on Kisiwa Panza.

\section{Status on Chumbe Island}

Studies of coconut crabs on Chumbe Island have been based out of the Eco-Lodge, which hosts research projects. Unfortunately, these studies used different methodologies, some of which depended on questionable assumptions such as a closed population, random sampling and constant catchability. In April 1999 Bruggers (1999) reported > 1,000 coconut crabs on Chumbe but assumed equivalent densities across the island, which was subsequently found to be erroneous. In April 2003 King (2003) calculated a total population size of 354 crabs using the Schnabel method of mark-recapture. In November 2004 Roop (2004) used the same baiting site locations as King (2003) and estimated the crab population to be 1,761, and in November 2010 Singh (2010) baiting at the same sites and using the same methods captured 88 more crabs than Roop (2004). In February 2013 Kilströmer \& Bergwall (2013) used the Lincoln-Peterson mark-recapture index and estimated the coconut crab population on Chumbe to be 446 crabs. Despite the regularity of these island censuses (five times in 14 years), estimates of the population size vary widely, probably as a result of differences in the number of baiting stations and differences in timing of studies over the year. Nonetheless, the size of animals captured and the sex ratios suggest an increasing or stable population of considerable size on Chumbe, although these population counts may be subject to error.

\section{Conservation recommendations}

Our data showing that larger subpopulations are found in the presence of crops and farther away from people, and that the heaviest adult coconut crabs are found on more remote island reserves and where crabs are not exploited, are of concern and suggest that assessment of the coconut crab's extinction risk is overdue. Threats from habitat destruction are a conservation concern in many places (IUCN, 2016). The species receives different degrees of protection dependent on the country. There is no legal protection for coconut crabs in Tanzania as a whole, and enforcing protection measures outside reserves is a challenge. Yet in other places, such as the Glorieuses Islands and the Christmas Island National Park in the Indian Ocean, the species is fully protected (James, 2007; Poupin et al., 2013). Less stringent protection of coconut crab populations occurs in Japan,
Guam, Vanuatu, the Philippines and Indonesia, where collection of crabs during the breeding season is prohibited or collection of small individuals is forbidden. In addition, there are taboos against eating coconut crabs on Nicobar Island (Patankar \& D'Souza, 2012). Our findings indicate there may be conservation actions of general significance that may be worth pursuing.

In 2016 some of the authors produced a poster, with the Department of Forestry and Non-Renewable Natural Resources about the biology and conservation of coconut crabs, which was distributed to most shehias across Pemba. This educational campaign was implemented in the schools in Pemba, with variable success (the posters were typically absent from schools in subsequent years). Based on this experience, we recommend that conservation efforts should be focused on the shehias in Pemba where coconut crabs are still abundant, specifically targeting the villages and fishers' camps for conservation activities. This programme will involve working with Shehia Conservation Committees that already exist to determine their willingness to participate in educational campaigns, the zoning of protected areas, the organization of workshops with local government and local NGOs, and discussions with schoolchildren about their environment. It is likely that a dedicated education/awareness programme targeting children could reduce or eliminate coconut crab exploitation in the north-west of Pemba, on Fundo Island and on Kisiwa Panza. As children learn foraging skills from each other, it is likely that changing children's attitudes and behaviour, combined with altering the attitudes of adult men, who have control over family issues, is the best way of achieving results on Pemba.

Specifically, we recommend that sanctuaries are established at Swahili Divers and Verani Beach Hotel and nighttime coconut crab walks for fee-paying tourists be initiated, led by local guides from nearby villages. This idea could also be implemented on Fundo Island, which is sometimes visited by tourists, at Wambaa near the Fundo Lagoon Lodge, and on Jumbe Island on Kisiwa Panza where the nearby Emerald Bay Hotel already arranges boat trips around Jumbe Island (Fig. 2b). All these proposals link nearby hotels with coconut crab protection and have the potential to provide revenue from tourism to local communities. Careful design is needed to ensure that income from such fees trickles down to all members of the community. In addition, revenue to young adults and teenagers would be an incentive to ensure that they control crab offtake by children.

Its large size, great strength and striking coloration (Caro et al., 2019), make the coconut crab a charismatic megainvertebrate, and its reputation for climbing coconut palm trees, dislodging coconuts and returning to the ground to harvest them drew the attention of Charles Darwin (1839). Tourists visiting tropical islands are interested in seeing these increasingly rare animals, and searching for coconut 
crabs at night adds a sense of adventure and creates an opportunity to involve local people as tourist guides. This in turn provides a funding source for nearby communities that could foster increased conservation awareness. Coconut crab conservation will ultimately depend on the willingness of local communities to protect these animals in exchange for economic compensation. Fortunately, many of the tropical islands on which coconut crabs still occur are tourist havens and this offers the possibility of forging links between the tourist industry and local communities for the benefit of these charismatic but threatened crustaceans.

Acknowledgements We thank the Revolutionary Government of Zanzibar, the Department of Non-Renewable Natural Resources, the Department of Fisheries, Pemba, and Chumbe Island Coral Park for permissions. We are grateful to Scarlet and Don Hibner and University of California Davis for their financial support.

Author contributions Conception of distribution study: TC, MBM; distribution fieldwork HH, RSR, BC; crab measurements: TC, UK, VMM, ON; preparation of maps: IP; writing: TC; revisions: NC, MBM, OS, VMM.

\section{Conflicts of interest None.}

Ethical standards Conducted under University of California Davis Institutional Review Board ID 991486-1 for human subjects, and otherwise abided by the Oryx guidelines on ethical standards.

\section{References}

Abdullah, A., Hamad, A.S., Ali, A.M. \& Wild, R.G. (1997) Misali Island, Tanzania-an open access resource redefined. In 8 th Biennial Conference of the International Association for the Study of Common Property. Constituting the Commons: Crafting Sustainable Commons in the New Millennium. Misali workshop 11-13 August 1997, Misali, Tanzania.

Amesbury, S.S. (1980) Biological Studies on the Coconut Crab (Birgus latro) in the Mariana Islands. Agriculture Experiment Station, Technical Report No. 17. University of Guam, Mangilao, Guam.

Bowers, M. (2006) Academic arthropods: operant conditioning in the coconut crab (Birgus latro) on Misali Island. Wildscreen Arkive, 19 May 2006. arkive.org/coconutcrab/birgus-latro [accessed 2017].

Brown, I.W. \& Fielder, D.R. (eds) (1991) The Coconut Crab: Aspects of the Biology and Ecology of Birgus latro in the Republic of Vanuatu. Australian Centre for International Agricultural Research, Canberra, Australia.

Bruggers, S. (1999) Coconut Crab (Birgus latro) Demographics on Chumbe. Unpublished report. School for International Training, Spring 1999, Battleboro, USA.

Caro, T., Cluff, E. \& Morgan, V.M. (2019) Colour polymorphism and protective coloration in coconut crabs. Ethology Ecology \& Evolution, 31, 514-525.

Caro, T. \& Morgan, V.M. (2018) Striving to protect robber crabs in Tanzania. Swara, October-December 2018, 55-57.

Darwin, C. (1839) Narrative of the Surveying Voyages of His Majesty's Ships Adventure and Beagle. Henry Colburn, London, UK.

Drew, M.M., Harzsch, S., Stensmyr, M., Erland, S. \& Hansson, B.S. (2010) A review of the biology and ecology of the robber crab, Birgus latro (Linnaeus, 1767) (Anomura: Coenobitidae). Zoologischer Anzeiger, 249, 45-67.
Drew, M.M., Hartnoll, R.G. \& Hansson, B.S. (2012) An improved mark-recapture method using passive integrated transponder (PIT) tags in Birgus latro (Linnaeus, 1767) (Decapoda, Anomura). Crustaceana, 85, 89-102.

Eldredge, L.G. (1996) Birgus latro. In The IUCN Red List of Threatened Species 1996: e.T2811A9484078. dx.doi.org/10.2305/IUCN.UK.1996. RLTS.T2811A9484078.en [acccessed 30 January 2020].

Fletcher, W.J. (1969) Coconut crabs. The Sciences, 9, 26-27.

Fletcher, W.J. (1993) Coconut crabs. In Nearshore Marine Resources of the South Pacific: Information for Fisheries Development and Management. Suva, Fiji (eds A. Wright \& L. Hill), pp. 643-681. International Centre for Ocean Development, Forum Fisheries Agency, Honiara, Solomon Islands.

Fletcher, W.J., Brown, I.W. \& Fielder, D.R. (1990) Growth of the coconut crab Birgus latro in Vanuatu. Journal of Experimental Marine Biology and Ecology, 141, 63-78.

IUCN (2016) The IUCN Red List of Threatened Species 2018-1. iucnredlist.org [accessed 28 December 2018].

James, D.J. (2007) Population Structure and Road Mortality in Red Crabs (Gecarcoidea natalis) and Robber Crabs (Birgus latro) on Christmas Island. Report to Department of Finance \& Administration, and Department of the Environment \& Water Resources, City, Country.

Kilströmer, A. \& Bergwall, E. (2013) Population Study of the Coconut Crab (Birgus latro) On the Islands of Chumbe and Mnemba, Tanzania. Unpublished report. University of Gothenburg, Gothenburg, Sweden.

KING, G. (2003) Coconut Crab (Birgus latro) Demographics on Chumbe. Unpublished report. School for International Training Spring 2003, Battleboro, USA.

Klein, L. \& St. Denis, A. (2016) An Evaluation of Coconut Crab Populations and Management on Misali Island, Pemba. Unpublished report. School for International Training, Fall 2006, Battleboro, USA.

Laidre, M.E. (2018) Coconut crabs. Current Biology, 28, R51-R65. Lew-Levy, S., Reckin, R., Lavi, N., Cristtobal-Azkaratte, J. \& Ellis-Davies, K. (2017) How do hunter-gatherer children learn subsistence skills? A meta-ethnographic review. Human Nature, $28,367-394$.

Merritt, H. (2014) Coconut Crab (Birgus latro) Survey on Misali Island, Pemba. Unpublished report. Independent study project, circulated privately.

Ока, S.I., Томіта, T. \& Мiуамото, K. (2016) A mighty claw: pinching force of the coconut crab, the largest terrestrial crustacean. PLOS ONE, 11, e0166108.

Nokelainen, O., Stevens, M. \& Caro, T. (2018) Colour polymorphism in the coconut crab (Birgus latro). Evolutionary Ecology, 32, 75-88.

Patankar, V. \& D'Souza, E. (2012) Conservation needs of the coconut crab Birgus latro on the Nicobar Islands, India. Oryx, 46, 175-178.

Poupin, J., Zubia, M., Gravier-Bonnet, N., Chabanet, P. \& Duhec, A. (2013) Crustacea Decapoda of the Glorieuses Islands, with notes on the distribution of the coconut crab (Birgus latro) in the western Indian Ocean. Marine Biodiversity Records, 6, e215.

Reyne, A. (1939) On the food habits of the coconut crab (Birgus latro L.) with notes on its distribution. Archives Néerlandaises de Zoologie, 3, 239-247.

Roop, J. (2004) Coconut Crab (Birgus latro) Behavior on Chumbe. Unpublished report. School for International Training, Fall 2004, Battleboro, USA.

SingH, K. (2010) Birgus latro Population Dynamics on Chumbe Island: Coconut Crab Population Health and Recruitment. Unpublished report. School for International Training, Fall 2010, Battleboro, USA. 